\title{
Does Immateriality Matter? Evidence from Accountants Concerning the Acceptability of Questionable Accounting Practices
}

\author{
Wen Chang ${ }^{1}$, Mien-Ling Chen ${ }^{1 *}$, Chi-Ying Chiao ${ }^{1,2}$ \\ ${ }^{1}$ Department of Accounting Information, Hsing Wu Institute of Technology, New Taipei City, Chinese Taipei \\ ${ }^{2}$ Department of Ph.D. Program in Graduate School of Management, Chung Yuan Christian University, Chung Li, Chinese Taipei \\ Email: \{084012, *085006, 078004\}@mail.hwc.edu.tw
}

Received January 16, 2012; revised February 18, 2012; accepted February 27, 2012

\begin{abstract}
Questionable accounting practices, sometimes, cause from misusing the concept of materiality to manage their reported earnings. The purpose of this study is to examine the attitudes of accountants concerning the acceptability of 14 questionable accounting practices from the amount of material and immaterial perspectives. The results show that, for all 14 questionable accounting practices, the differences in acceptability between the amount of materiality and immateriality were all statistically significant. Regarding the amount of immateriality, especially for questionable, but still legal accounting practices, accountants appear to have the higher average level of acceptability under the extreme pressure from the top management. While questionable accounting practices are clearly illegal, no matter what the amount is material or immaterial, accountants appear to have the lowest average level of acceptability. This finding may be helpful for businesses and professional associations as they develop their own policies, standards and educational programs regarding dealing with questionable accounting practices.
\end{abstract}

Keywords: Immateriality; Accountants; Questionable Accounting Practices; Acceptability

\section{Introduction}

Accounting fraud in financial statements has been and continues to be a topic of importance for accounting professionals and academics. Especially, in the early 2000s, a wave of accounting scandals such as Enron, Xerox and WorldCom, rocked the accounting world and public confidence in the accounting profession. Accounting is the language of business that provides information about the financial position of an organization or business. The financial information is critical to the firm's officers, investors, lenders, and general public because this information may change or influence their benefits or decisions. Therefore, it is not uncommon to find that managers engage in questionable accounting practices to manage earnings in order to meet analyst' $\mathrm{s}$ estimates and influence the stock market, or to reach targets set by compensation contracts or debt covenants (Nelson, Elliott, and Tarpley [1]).

Nelson et al. [1] indicate that managers attempt to manage earnings through accounting practices that are consistent with GAAP (e.g., leaseback), difficult to distinguish from GAAP (e.g., understating bad debts), and clearly not GAAP (e.g., intentionally misapplying reve-

${ }^{*}$ Corresponding author. nue recognition rules). Beasley and Hermanson [2] point out that "many accounting fraud cases begin with activeties that might be characterized as in the gray zone: not completely acceptable, but not clearly inappropriate (pp. 12)". Levitt [3] in his "The Numbers Game" speech argued that companies and their auditors were abusing materiality guidelines in order to manipulate their earnings, and when they are questioned about these clear violations of GAAP, their answers are "It doesn't matter. It's immaterial”.

Although much of the research has focused on earnings management from questionable accounting practices (Nelson et al. [1]; Prwaitt, Smith, and Wood [4]), little research has investigated questionable accounting practices from material and immaterial perspectives. However, questionable accounting practices, sometimes, cause from misusing the concept of materiality to manage their reported earnings.

This study focuses on instances of questionable accounting practices that are difficult to distinguish from GAAP or clearly not GAAP. Yet, many questionable accounting practices may be immaterial, and therefore not attract public scrutiny, and many questionable accounting practices may be attempted by management but 
prevented by outside auditors. However, whether the information is material that depends on the size or nature of the item, or a combination of both (IAASB 2004), and in light of surrounding circumstances, the judgment of a reasonable person relying upon this information would have been changed or influenced by the inclusion or correction of the item (FASB 1980). The purpose of this study is to examine the attitudes of accountants concerning the acceptability of questionable accounting practices from the amount of material and immaterial perspectives.

Knowing current attitudes toward questionable accounting practices from material and immaterial perspectives will be helpful for businesses and professional associations as they develop their own policies, standards and educational programs regarding dealing with questionable accounting practices.

\section{Questionable Accounting Practices}

Most questionable accounting practices involve premature revenue recognition, fictitious revenues, fictitious assets and/or reductions of expenses/liabilities, overstated assets and understated expenses/liabilities, inappropriate disclosures, and related party transactions etc (Bonner, Palmrose, and Young [5]; Beasley, Carcello, and Hermanson [6]). Beasley et al. [6] in their "Fraudulent financial reporting: 1987-1997", find that over half the frauds involved overstating revenues by recording revenues prematurely or fictitiously. About half the frauds involved overstating assets by understating bad debts, overstating the value of inventory, property, plant and equipment and other tangible assets, and recording assets that did not exist.

Fictitious revenues and fictitious assets are fictitious transactions can be supported by fake documents and collusions with third parties. For example, accountants can create evidence to justify fictitious revenues through fake documents such as fake invoices, fake shipping documents, and fake purchase orders, as well as collusions with customers. Similar to fictitious inventory can be perpetrated and concealed through fake documents and collusions with suppliers.

Unlike fictitious transactions, premature revenue recognition, overstated assets and understated expenses/ liabilities have existent transactions. Premature revenue recognition involves recording sales after the goods were ordered but before they were shipped to the customer, recognized total revenues with multi-year contracts as the first-year operating revenues, or recognized revenues when distribute products to dealers, etc. Bonner et al. [5] indicate that intentionally overstating sales by creating phony invoices may be considered to be a more egregious fraud than intentionally overstating sales using otherwise legitimate shipments alter the end of the period.
Overvalued assets and undervalued expenses involve understating bad debts, understating estimated liability under warranties, choosing favorable asset valuation methods to avoid recognizing impairment loss, or not willing to write off obsolete assets in order to avoid disposal asset loss, etc.

Additional questionable accounting practices involve inappropriate disclosures, such as inadequately disclose derivatives transactions, failure to disclose the negotiable certificate of deposite (NCD) as the pledge security, inadequately disclose related party transactions in financial statements, or failure to disclose pending lawsuits in order to conceal probable liability, etc. Other questionable accounting practices involve related party transactions, such as regarding no substantial purchase agreement still prepay in order to transfer cash to the related party, or booked "related party receivables" as "accounts receivables" in order to conceal the related party transactions.

\section{Methods}

\subsection{Sample and Data Collection}

A total of 500 survey packets were distributed to accountants with a convenience sample by visiting managers in Taiwan CPA firms, and asking mangers to help distributing the survey packet to accountants and mail it back. Each packet contained a cover letter, a questionnaire and a postage-paid return envelope. One hundred fourteen usable responses were received, providing a response rate of approximately $22.8 \%$. Most respondents are female $(78.1 \%)$. A large of portion of respondent (50\%) were 30 years of age or older and most of them (51.8\%) had at least five years' experience in their occupation.

\subsection{Instrument and Measures}

The questionnaire consisted of one scenario, 14 questionable accounting practices and demographic items. Respondents were first asked to read the scenario as the following:

An accountant is in the condition that he/she is instructed to employ the 14 questionable accounting practices under the extreme pressure from the top management. This job and salary is very important to him/her and his/her family, and he/she gets a hint if he/she doesn't follow the instruction, he/she may get lay off.

Then, in this condition, respondents are asked if they were this accountant, from the amount of materiality and immateriality perspectives respectively, to rank the degree to which they felt the questionable accounting practices described in each statement was acceptable using a seven point Likert-type scale (ranging from never acceptable, “1”, to always acceptable, “7”). Thus, higher 
mean response scores suggest a higher degree of acceptability for the questionable accounting practices. Fourteen questionable accoutning practices involve 1) premature revenue recognition; 2) fictitious revenues; 3) fictitious assets and/or reductions of expenses/liabilities; 4) overstated assets and understated expenses/liabilities; 5) related party transactions; and 6) inappropriate disclosure. These questionable accoutning practices were developed based on existing research (Bonner et al. [5]; Elias [7]; Emerson, Conroy, and Stanley [8]) and practitioner literaures (NACFE [9]) on accounting frauds.

\subsection{Data Analysis}

Because our data are ordered responses with regard to the acceptability of questionable accounting practices, a nonparametric Wilcoxon matched-pair test was used to compare accountants' responses regarding the amonut of materiality and immateriality in each questionable accounting practice, and to test whether their concerns differ.

\section{Results}

\subsection{Descriptive Statistics}

Descriptive statistics for rating the acceptability of each questionable accounting practice on a scale where $1=$ never acceptable and 7 = always acceptable, are presented in Table 1. Regarding the amount of materiality, all questionable accounting practices have mean response scores significantly lower than 4 (at the $0.1 \%$ level of statistical significance). In addition, three of 14 questionable accounting practices have median response scores 1 . These three questionable accounting practices are "booked financing from a bank as operating revenues in order to inflate revenues and conceal debts," "booked cancelled bill as revenues," and "creating other receivables to conceal the misuse of the company's funds," and are related to fictitious revenues and fictitious assets. This implies that most accountants will never engage in these three questionable accounting practices with the amount of materiality, even though they are under the extreme pressure from the top management.

Table 1. Descriptive statistics for concerning the acceptability of questionable accounting practices $(\mathbf{n}=114)$.

\begin{tabular}{|c|c|c|c|c|c|c|}
\hline \multirow{2}{*}{ Brief description } & \multicolumn{3}{|c|}{ Materiality } & \multicolumn{3}{|c|}{ Immateriality } \\
\hline & Mean & Median & SD & Mean & Median & SD \\
\hline \multicolumn{7}{|l|}{ Premature revenue recognition } \\
\hline $\begin{array}{l}\text { Recognized revenues after the goods were ordered but } \\
\text { before they were shipped to the customer }\end{array}$ & 2.00 & 2 & 1.440 & 3.11 & 3 & 1.626 \\
\hline $\begin{array}{l}\text { 2. Recognized total revenues with multi-year contracts as } \\
\text { the first-year operating revenues }\end{array}$ & 1.97 & 2 & 1.101 & 2.75 & 2 & 1.456 \\
\hline \multicolumn{7}{|l|}{ Fictitious revenues } \\
\hline $\begin{array}{l}\text { 3. Booked financing from a bank as operating revenues in } \\
\text { order to inflate revenues and conceal debts }\end{array}$ & 1.73 & 1 & 1.083 & 2.46 & 2 & 1.471 \\
\hline 4. Booked cancelled bill as revenues & 1.75 & 1 & 1.110 & 2.68 & 2 & 1.631 \\
\hline \multicolumn{7}{|l|}{ Fictitious assets and/or reductions of expenses } \\
\hline 5. Creating other receivables to conceal the misuse of the company's funds & 1.90 & 1 & 1.463 & 2.61 & 2 & 1.707 \\
\hline 6. Booked operating expenses as capital expenditures to inflate assets & 2.28 & 2 & 1.473 & 3.10 & 3 & 1.523 \\
\hline \multicolumn{7}{|l|}{ Overstated assets and understated expenses/liabilities } \\
\hline 7. Understating bad debts to overstate income and assets & 2.24 & 2 & 1.319 & 3.28 & 3 & 1.643 \\
\hline $\begin{array}{l}\text { 8. Understating estimated liability under warranties to increase } \\
\text { net income and decrease liability }\end{array}$ & 2.24 & 2 & 1.257 & 2.94 & 3 & 1.536 \\
\hline 9. Choosing favorable asset valuation methods to avoid recognizing impairment loss & 2.91 & 3 & 1.701 & 3.71 & 4 & 1.774 \\
\hline 10. Not willing to write off obsolete assets in order to avoid disposal asset loss & 2.39 & 2 & 1.436 & 3.47 & 3 & 1.720 \\
\hline \multicolumn{7}{|l|}{ Related party transactions } \\
\hline $\begin{array}{l}\text { Regarding no substantial purchase agreement still prepay in } \\
\text { order to transfer cash to the related party }\end{array}$ & 2.03 & 2 & 1.313 & 2.74 & 3 & 1.613 \\
\hline $\begin{array}{l}\text { Booked "related party receivables" as "accounts receivables" } \\
\text { in order to conceal the related party transactions }\end{array}$ & 2.25 & 2 & 1.329 & 3.01 & 3 & 1.472 \\
\hline \multicolumn{7}{|l|}{ Inappropriate disclosure } \\
\hline 13. Inadequately disclose derivatives transactions & 2.40 & 2 & 1.260 & 3.13 & 3 & 1.560 \\
\hline 14. Failure to disclose pending lawsuits in order to conceal probable liability & 2.05 & 2 & 1.104 & 3.06 & 3 & 1.609 \\
\hline
\end{tabular}


Regarding the amount of immateriality, all but one questionable accounting practice have mean response scores significantly lower than 4 (at the $0.1 \%$ level of statistical significance). This practice is "choosing favorable asset valuation methods to avoid recognizing impairment loss", implying that accountants have the highest average level of acceptability regarding this practice. None of 14 questionable accounting practices have median response scores 1 . Most accountants rating the acceptability of each questionable accounting practice from 2 to 3, implying that they will take "the amount of immateriality" into consideration when they are instructed to engage in theses questionable accounting practices under the extreme pressure from the top management.

\subsection{Comparisons of the Acceptability between the Amount of Materiality and Immateriality}

A comparsion of the acceptability between the amount of materiality and immateriality for each of 14 questionable accounting practices is presented in Table 2 . Analysis of these differences is done by a nonparametric Wilcoxon matched-pair test. For all 14 questionable accounting practices, the differences in acceptability between the amount of materiality and immateriality were all statistically significant ( $p<0.0001$ ). The 3 top-ranking differences according to z-statistics were 1) failure to disclose pending lawsuits in order to conceal probable liability; 2) not willing to write off obsolete assets in order to avoid disposal asset loss; and 3) understanding bad debts to overstate income and assets. This implies that accountants are likely to take "the amount of immateriality" into consideration when they decide whether or not to engage in these 14 questionable accounting practices under the extreme pressure from the top management, especially for the 3 top-ranking differences of accounting practices.

As shown in Table 2, seven of 14 questionable accounting practices, over 50\% (57/114) accountants have

Table 2. A comparsion concerning the acceptability of questionable accounting practices between the amount of materiality and immateriality using the Wilcoxon matched-pair test $(n=114)$.

\begin{tabular}{|c|c|c|c|c|}
\hline \multirow{2}{*}{ Brief description } & \multirow[b]{2}{*}{ Tie $(\mathrm{N})$} & \multicolumn{2}{|c|}{ Mean Rank (Immaterial-Material) } & \multirow{2}{*}{$\mathrm{Z}^{\mathrm{a}}$} \\
\hline & & Negative $(\mathrm{N})$ & Positive (N) & \\
\hline \multicolumn{5}{|l|}{ Premature revenue recognition } \\
\hline $\begin{array}{l}\text { 1. Recognized revenues after the goods were ordered but before } \\
\text { they were shipped to the customer }\end{array}$ & 43 & $26.32(11)$ & $37.78(60)$ & -5.771 \\
\hline $\begin{array}{l}\text { 2. Recognized total revenues with multi-year contracts as the first-year } \\
\text { operating revenues }\end{array}$ & 46 & $23.57(14)$ & $37.33(54)$ & -5.241 \\
\hline \multicolumn{5}{|l|}{ Fictitious revenues } \\
\hline $\begin{array}{l}\text { 3ooked financing from a bank as operating revenues in order to inflate } \\
\text { revenues and conceal debts }\end{array}$ & 52 & $24.85(10)$ & $32.78(52)$ & -5.205 \\
\hline 4. Booked cancelled bill as revenues & 53 & $16.00(7)$ & $32.94(54)$ & -6.062 \\
\hline \multicolumn{5}{|l|}{ Fictitious assets and/or reductions of expenses/liabilities } \\
\hline 5. Creating other receivables to conceal the misuse of the company's funds & 56 & $26.46(12)$ & $30.29(46)$ & -4.221 \\
\hline 6. Booked operating expenses as capital expenditures to inflate assets & 32 & $45.81(13)$ & $40.69(69)$ & -5.201 \\
\hline \multicolumn{5}{|l|}{ Overstated assets and understated expenses/liabilities } \\
\hline 7. Understating bad debts to overstate income and assets & 39 & $28.72(9)$ & $39.27(66)$ & -6.243 \\
\hline $\begin{array}{l}\text { 8. Understating estimated liability under warranties to increase net } \\
\text { income and decrease liability }\end{array}$ & 47 & $29.04(14)$ & $35.31(53)$ & -4.652 \\
\hline 9. Choosing favorable asset valuation methods to avoid recognizing impairment loss & 41 & $25.60(15)$ & $39.95(58)$ & -5.405 \\
\hline 10. Not willing to write off obsolete assets in order to avoid disposal asset loss & 42 & $21.10(10)$ & $39.98(62)$ & -6.260 \\
\hline \multicolumn{5}{|l|}{ Related party transactions } \\
\hline $\begin{array}{l}\text { Regarding no substantial purchase agreement still prepay in order to } \\
\text { transfer cash to the related party }\end{array}$ & 56 & $25.38(8)$ & $30.16(50)$ & -5.152 \\
\hline $\begin{array}{l}\text { 12. Booked "related party receivables" as"accounts receivables" in order } \\
\text { to conceal the related party transactions }\end{array}$ & 46 & $26.41(11)$ & $36.06(57)$ & -5.542 \\
\hline \multicolumn{5}{|l|}{ Inappropriate disclosure } \\
\hline 14. Failure to disclose pending lawsuits in order to conceal probable liability & 49 & $22.67(3)$ & $33.50(62)$ & -6.663 \\
\hline
\end{tabular}

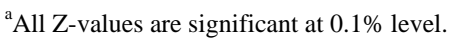


positive differences. Three of these seven questionable accounting practices are related to overstated assets and understated expenses. These three questionable accounting practics are "understanding bad debts to overstate income and assets", "choosing favorable asset valuation methods to avoid recognizing impairment loss," and "not willing to write off obsolete assets in order to avoid disposal asset loss". Two of these seven questionable accounting practices are "recognized revenues after the goods were ordered but before they were shipped to the customer", and "booked operating expenses as capital expenditures to inflate assets". These two practices are related to premature revenue recongition, and fictitious assets and reductions of expenses, respectively. For the remaining two questionable accounting practices are "booked related party receivables as accounts receivables in order to transfer cash to the related party" and "failure to disclose pending lawsuits in order to conceal probable liability". These two practices are related to related party transactions and inappropriate disclosure, respectively.

\section{Discussion}

"Booked financing from a bank as operating revenues in order to inflate revenues and conceal debts", "booked cancelled bill as revenues", and "creating other receivables to conceal the misuse of the company's funds," these three accounting practices involve concealment of unlawful transactions. Interntional immaterial misstatements by accountants have always been prohibited by the secunities acts. Therefore, under the extreme pressure from the top management, no matter what the amount is material or immaterial, accountants appear to have the lowest average level of acceptability for these three questionable accounting practices. "Recognized revenues after the goods were ordered but before they were shipped to the customer" and "booked operating expenses as capital expenditures to inflate assets” are illegally ambiguous in the amount of immaterialitly. Therefore, these two accounting practices are not likely driving down the responses as other illegal accounting practices in the amount of immateriality.

"Understanding bad debts to overstate income and assets", "choosing favorable asset valuation methods to avoid recognizing impairment loss", and "not willing to write off obsolete assets in order to avoid disposal asset loss, these three accounting practices invlove earning management, and while ethically questionable, are still legal. Therefore, regarding the amount of immateriality, under the extreme pressure from the top management, accountants appear to have the higher average level of acceptability for these three questionable accounting practices, especially for "choosing favorable asset valuation methods to avoid recognizing impairment loss”.
Regarding the amount of materiality, "failure to disclose pending lawsuits in order to conceal probable liability" may affect the registrant's compliance with loan covenants or other contractual requirements, while the amount of immateriality may not. This reason could be interpreted by accountants taking this practice into consideration when the amount is immaterial.

\section{Conclusions}

Under the extreme pressure from practices, accountants are likely to engage in questionable accounting practices when the amount is immaterial. Especially for legal accounting practices, accountants appear to have the higher average level of acceptability. While questionable accounting practices are clearly illegal, no matter what the amount is materail or immaterial, accountants apear to have the lowest average level of acceptability. This finding may be helpful for businesses and professional associations as they develop their own policies, standards and educational programs regarding dealing with questionable accounting practices.

The results of our study are subject to a number of limitations. First, the data consisted solely of accountants' perceptions, which is always a concern. Second, it is problematic to question accountants about their engagement in questionable accounting practices because they may not wish to disclose information about such behavior. Finally, since this study relies on a convenience sample from only 114 accountant's respondents in Taiwan, the results are not generalizable to other accountant considerations.

\section{REFERENCES}

[1] M. W. Nelson, J. A. Elliott and R. L. Tarpley, "How Are Earning Managed? Example from Auditors,” Accounting Horizons, Supplement, 2003, pp. 17-35.

[2] M. S. Beasley and D. R. Hermanson, "Going beyond Sarbanes-Oxley Compliance: Five Keys to Creating Value," CPA Journal, Vol. 74, No. 6, 2004, pp. 11-13.

[3] A. Levitt, “The Numbers Game,” Speech Delivered at the NYU Center for Law and Business, New York, 28 September 1998.

[4] D. F. Prawitt, J. L. Smith and D. A. Wood, "Internal Audit Quality and Earnings Management," The Accounting Review, Vol. 84. No. 4, 2009, pp. 1255-1280. doi:10.2308/accr.2009.84.4.1255

[5] S. E. Bonner, Z. V. Palmrose and S. M. Young, "Fraud Type and Auditor Litigation: An Analysis of SEC Accounting and Auditing Enforcement Releases," The Accounting Review, Vol. 73, No. 4, 1998, pp. 503-532.

[6] M. S. Beasley, J. V. Carcello and D. R. Hermanson, "Fraudulent Financial Reporting: 1987-1997 An Analysis of US Public Companies," Committee of Sponsoring Organizations of the Treadway Commission, AICPA, Jersey 
City, 1999.

[7] R. Z. Elias, "Determinants of Earnings Management Ethics among Accountants," Journal of Business Ethics, Vol. 40, No. 1, 2002, pp. 33-45. doi:10.1023/A:1019956821253

[8] T. L. N. Emerson, S. J. Conroy and C. W. Stanley, "Ethical Attitudes of Accountants: Recent Evidence from a
Practitioners' Survey,” Journal of Business Ethics, Vol. 71, No. 1, 2007, pp. 73-87. doi:10.1007/s10551-006-9125-2

[9] National Association of Certified Fraud Examiners (NACFE), "Cooking the Books: What Every Accountant Should Know about Fraud. Austin,” NACFE, 1992. 